\title{
Early diet of preterm infants and development of allergic or atopic disease: randomised prospective study
}

\author{
A Lucas, O G|Brooke, R Morley, T J Cole, M F Bamford
}

\begin{abstract}
Objective-To study the effect of early diet on the development of allergic reactions in infants born preterm.

Design-Two randomised prospective trials. In trial A infants were randomly allocated banked donor milk or preterm formula as their sole diet or (separately randomised) as a supplement to their mother's expressed breast milk. In trial B infants were allocated term or preterm formula. A blind follow up examination was done 18 months after the expected date of birth.
\end{abstract}

Setting-Neonatal units of hospitals in Cambridge, Ipswich, King's Lynn, Norwich, and Sheffield. Outpatient follow up.

Participants -777 Infants with a birth weight $<1850$ g born during 1982 to 1984 .

Main outcome measures-Development of eczema, allergic reactions to food or drugs, and asthma or wheezing by nine and 18 months after term. Whenever possible the observations were confirmed by rechallenge or clinical examination.

Results-At 18 months after term there was no difference in the incidence of allergic reactions between dietary groups in either trial. In the subgroup of infants with a family history of atopy, however, those in trial $\mathbf{A}$ who received preterm formula rather than human milk had a significantly greater risk of developing one or more allergic reactions (notably eczema) by 18 months (odds ratio $3 \cdot 6$; $95 \%$ confidence interval 1.4 to $9 \cdot 1$ ).

Conclusions-Feeding neonates on formulas based on cows' milk, including those with a high protein content, did not increase the overall risk of allergy. Nevertheless, in the subgroup with a family history of atopy early exposure to cows' milk increased the risk of a wide range of allergic reactions, especially eczema.

MRC Dunn Nutrition Unit, Cambridge CB4 1XJ

A Lucas, MRCP, clinical scientist, Medical Research Council

O G Brooke, MD, visiting research worker

R Morley, MB, clinical scientist, Medical Research

Council

T J Cole, PHD, senior scientist, Medical Research Council

Ipswich Hospital, Ipswich, Suffolk IP4 5PD

M F Bamford, MB, consultant paediatrician

Correspondence to: Dr Lucas. exposure might result from reduced digestion of protein, ${ }^{2}$ increased gut permeability, ${ }^{3}$ the increased likelihood of aspiration of milk, ${ }^{4}$ or an increased load of food antigens per unit of body weight than in more mature infants." Indeed, we have shown that the preterm neonate fed on formula milk rapidly develops latent anaphylactic sensitisation to cows' milk. ${ }^{5}$

It is therefore reasonable to question whether early exposure to cows' milk formula, particularly the relatively high protein preterm formula, might result in a raised incidence of later allergic or atopic disease. We have studied the incidence of allergic or atopic disease in a population of premature infants followed up until 18 months after term.

\section{Subjects and methods}

STUDY POPULATION

The 777 infants in this investigation were taking part in a five centre study investigating the effects of the early diet of preterm infants on subsequent outcome ${ }^{6}$; they were followed up until 18 months after their expected date of delivery. They were recruited, with informed parental consent, from hospitals in Cambridge, Ipswich, King's Lynn, Norwich, and Sheffield. All weighed less than $1850 \mathrm{~g}$ at birth and did not have any major congenital abnormality. Their mean birth weight was 1397 (SD 298) $\mathrm{g}$ and mean gestation $31(2 \cdot 7)$ weeks.

\section{TRIAL DESIGN}

Infants were assigned randomly to their early diet in two parallel clinical trials stratified by the mother's intention to provide breast milk, the diet being stopped at the time of discharge from the neonatal unit or when a weight of $2000 \mathrm{~g}$ had been attained. Randomisation was by permuted blocks of variable length, with the dietary assignments in sealed numbered envelopes.

In trial $\mathrm{A}$, which was conducted in Cambridge, Ipswich, and King's Lynn, babies were assigned to receive either banked or donor breast milk or a special preterm formula(Osterprem, Farley Health Products), with infants whose mothers chose to provide breast milk $(n=308)$ randomised separately from those whose mothers elected not to express milk $(n=138)$. Thus when mothers chose to provide expressed breast milk infants were randomly assigned to receive supplements of banked milk or preterm formula as required. In trial B infants were assigned to receive a term formula (Osterfeed, Farley Health Products) or preterm formula as the sole diet $(n=118)$ or as a supplement to their mother's milk $(n=213)$. In both trials infants were combined into two groups regardless of whether the mother chose to provide breast milk so that comparisons were made between human milk and preterm formula (as a sole diet or supplement) and between term and preterm formulas (as a sole diet or supplement). 
The constituents of the preterm formula have been listed elsewhere. ${ }^{6}$ The concentration of cows' milk protein was $14.5 \mathrm{~g} / \mathrm{l}$ in the term formula and $20 \mathrm{~g} / \mathrm{l}$ in the preterm formula, both having a ratio of casein to whey of 40:60. In those infants whose mothers chose to provide breast milk the median intake of maternal milk was $46 \%$ of the volume consumed. We calculated that in trial $\mathrm{B}$ the mean dietary intake of cows' milk protein was $10.3 \mathrm{~g} / \mathrm{l}$ in infants fed the term formula as the sole diet or a supplement to breast milk and $14.4 \mathrm{~g} / \mathrm{l}$ in those receiving preterm formula.

In trial A infants randomised to receive donor milk were fed exclusively on human milk for a median of five weeks (upper and lower quartiles three and seven weeks). Infants in trial A were first seen for follow up at nine (SD 1) months after term and those in both trials were seen at 18 (1) months after term. At follow up information was collected on eczema, wheezing (asthma), and sensitivities to food and drugs and a detailed clinical and neurodevelopmental assessment was made (not discussed here). Whenever possible (for example, in the case of eczema) the history was confirmed by clinical examination. Details of atopic or allergic disease in the family were collected while the infant was in the neonatal unit.

A single observer ( $\mathrm{RM})$ recorded the historical data at Cambridge, Ipswich, King's Lynn, and Norwich achieving a follow up rate of over $95 \%$. Other observers collected data in Sheffield, but in all cases observers were blind to the infants' initial diet. The study was approved by the local health authority's ethics committee at each of the five hospitals and the Dunn Nutrition Unit.

\section{DIAGNOSES}

Reactions to specific foods (including those to cows' milk) were recorded for infants with a strong history of such reactions. They were usually gastrointestinal (loose stools or vomiting, or both) or a rash and had resulted in the foods being excluded from the diet. In some cases rechallenge under controlled conditions confirmed the diagnosis. Over $95 \%$ of recorded reactions to drugs presented as a rash.

The definition of asthma has been much debated.? Godfrey suggested that a diagnosis of asthma should be based on an intermittent increase in airway resistance, presenting as a cough or wheeze, which can be reversed, largely or completely, by bronchodilators or steroids. ${ }^{8}$ Whether recurrent untreated wheezing should be classified as asthma, however, is uncertain. We made considerable efforts to exclude other respiratory conditions characterised by noisy breathing - for example, mucous rattling - from our study.

Diagnosis of atopic eczema was based on a history of itchy dermatitis with characteristic distribution and was confirmed by clinical examination if signs were present at the time of follow up (91/151 cases were confirmed in this way). Seborrhoeic dermatitis was not classified as eczema.

\section{ANALYSES}

Analyses were performed to test the hypothesis that early diet influences the incidence of atopic or allergic disease. The difference in allergic reactions between diet groups was expressed as an odds ratio with a $95 \%$ confidence interval derived according to the method of Armitage." The interaction between diet and family history of allergy was tested with Student's $t$ test on the logarithm of the odds ratios for the two family history groups.

\section{Results}

Among the 446 infants randomly assigned to receive either human milk or preterm formula based on cows' milk in trial A no overall effect of diet was found on the development of reactions to cows' milk, other foods, or drugs or on the development of eczema, wheezing, or asthma (table I). The odds ratio for any one or more of these reactions was close to unity $(1 \cdot 1,95 \%$ confidence interval 0.8 to 1.6 ). Forty seven infants who were fed on breast milk alone for eight weeks or more (range eight weeks to five months) were compared with infants who were fed on breast milk alone for less than eight weeks and with infants fed on formula milk. There was no difference in the incidence of allergic or atopic disorders among these three groups. No difference was seen between those who received maternal milk and those whose mothers chose not to provide milk (data not shown). Similarly, in 331 infants who were followed up after random assignment to term formula or preterm formula milk there was no difference among the dietary groups in the incidence of atopic or allergic reactions (table II).

Of the 777 infants, 160 had first degree relatives with a history of atopic disease. Such diseases included one or more of eczema, asthma, hay fever, drug reactions, and confirmed food allergy. Seventy five of these infants were recruited to trial $\mathrm{A}$; those who received preterm formula showed a large increase in the overall incidence of allergic reactions or atopic disease at 18 months compared with those who received breast milk (table III): the odds ratio for developing eczema was $3.6(p<0.05)$, and the overall odds ratio for one or more allergic reactions was also $3.6(95 \%$ confidence intervals 1.4 to $9.1 ; \mathrm{p}<0.01)$. When there was no family history of allergy there were consistently fewer cases of all allergic reactions in infants who received preterm formula than in those who received human milk, but none of these differences was significant. Nevertheless, differences were observed in odds ratios between infants with and without a family history. Thus in infants who received preterm formula the odds ratio for developing eczema was 3.6 in those with a family history of atopy and 0.7 in those without a family history $(\mathrm{p}<0 \cdot 05)$. A similar differential impact of preterm formula between those with and without a family history was seen for the overall incidence of one or more allergic reactions $(\mathrm{p}<0 \cdot 01)$.

TABLE I-Number (percentage) of preterm infants who had developed eczema, allergic reactions, or asthma or wheezing at 18 months after term according to initial diet (banked breast milk or preterm formula as sole food or supplement to maternal milk)

\begin{tabular}{|c|c|c|c|}
\hline & $\underset{\substack{\text { milk } \\
(n=227)}}{\text { Human }}$ & $\begin{array}{l}\text { Preterm } \\
\text { formula } \\
(\mathrm{n}=219)\end{array}$ & $\begin{array}{c}\text { Odds ratio } \\
\text { (95\% confidence } \\
\text { interval) }\end{array}$ \\
\hline Eczema & $46(20)$ & $44(20)$ & $1.0(0.6$ to 1.6$)$ \\
\hline \multicolumn{4}{|l|}{ Reactions to: } \\
\hline Cows' milk & $10(4)$ & $7(3)$ & $0.7(0.3$ to 1.9$)$ \\
\hline All foods ${ }^{\star}$ & $22(10)$ & $24(11)$ & $1 \cdot 2(0 \cdot 6$ to $2 \cdot 1)$ \\
\hline Drugs & $15(7)$ & $16(7)$ & $1.1(0.5$ to 1.5$)$ \\
\hline Asthma or wheezing & $53(23)$ & $51(23)$ & $1.0(0.6$ to 1.5$)$ \\
\hline Total with any reaction & $99(44)$ & $100(46)$ & $1.1(0.8$ to 1.6$)$ \\
\hline
\end{tabular}

^Including cows' milk.

TABLE II - Number (percentage) of preterm infants who had developed eczema, allergic reactions, or asthma or wheezing at 18 months after eczema, allergic reactions, or asthma or wheezing at 18 months after
term according to initial diet (term or preterm formula as sole diet or supplement to maternal milk)

\begin{tabular}{|c|c|c|c|}
\hline & $\begin{array}{c}\text { Term } \\
\text { formula } \\
(\mathrm{n}=167)\end{array}$ & $\begin{array}{l}\text { Preterm } \\
\text { formula } \\
(n=164)\end{array}$ & $\begin{array}{c}\text { Odds ratio } \\
\text { (95\% confidence } \\
\text { interval) }\end{array}$ \\
\hline Eczema & $32(19)$ & $29(18)$ & $0.9(0.5$ to 1.6$)$ \\
\hline \multicolumn{4}{|l|}{ Reactions to: } \\
\hline Cows' milk & $9(5)$ & $8(5)$ & $0.9(0.3$ to 2.4$)$ \\
\hline All foods* ${ }^{\star}$ & $22(13)$ & $13(8)$ & $0 \cdot 6(0.3101 \cdot 2)$ \\
\hline Drugs & $9(5)$ & $5(3)$ & $0.6(0.2$ to 1.7$)$ \\
\hline Asthma or wheezing & $32(19)$ & $39(24)$ & $1.3(0.8102 \cdot 2)$ \\
\hline Total with any reaction & $73(44)$ & $69(42)$ & $0.9(0.6$ to 1.5$)$ \\
\hline
\end{tabular}

^Including cows' milk. 
IABLE III-- Number percentuge of preterm infunts ziho had developed eczema, allergic reactions, or wheezing or asthma at 18 months after term according to family history of ulops und initial diet

\begin{tabular}{|c|c|c|c|c|c|c|c|}
\hline & \multicolumn{3}{|c|}{ Family history of atopy } & \multicolumn{3}{|c|}{ No family history of atopy } & \multirow{2}{*}{$\begin{array}{c}\text { Interaction } \\
\text { between } \\
\text { family history } \\
\text { and diet } \\
\text { (p value) }\end{array}$} \\
\hline & $\begin{array}{c}\text { Human } \\
\text { milk } \\
(\mathrm{n}=38)\end{array}$ & $\begin{array}{c}\text { Preterm } \\
\text { formula } \\
(\mathrm{n}=-37)\end{array}$ & $\begin{array}{c}\text { Odds ratio } \\
95 \% \text { confidence } \\
\text { interval) }\end{array}$ & $\begin{array}{c}\underset{\text { Human }}{\text { milk }} \\
(\mathrm{n}=189) \\
\end{array}$ & $\begin{array}{l}\text { Preterm } \\
\text { formula } \\
(n=182)\end{array}$ & $\begin{array}{c}\text { Odds ratio } \\
\text { (95\% confidence } \\
\text { interval) }\end{array}$ & \\
\hline Eczema & $6(16)$ & $15(41)$ & $3 \cdot 6^{\star}(1 \cdot 2$ to 11$)$ & $40(21)$ & $29(16)$ & $0.7(0.4$ to 1.2$)$ & $<0.01$ \\
\hline \multicolumn{8}{|l|}{ Reactions to: } \\
\hline Cows' milk & $1(3)$ & $2(5)$ & $2 \cdot 1(0 \cdot 2$ to 25$)$ & $9(5)$ & $5(3)$ & $0.6(0.2$ to 1.7$)$ & \\
\hline All foods & $4(11)$ & $8(22)$ & $2.3(0.6$ to 8.3$)$ & $18(10)$ & $16(9)$ & $0.9(0.5$ to 1.9$)$ & \\
\hline Drugs & $1(3)$ & $6(16)$ & $7 \cdot 1(0 \cdot 8$ to 50$)$ & $14(7)=$ & $10(5)$ & $0.7(0.3$ to 1.7$)$ & \\
\hline Wheezing or asthma & $8(21)$ & $11(30)$ & $1.6(0.6$ to 1.4$)$ & $40(21)$ & $40(22)$ & $0.9(0.6$ to 1.5$)$ & \\
\hline Total with any reaction & $13(34)$ & $2465:$ & $3 \cdot 6^{\star}(1.4$ to $9 \cdot 1)$ & $86(46)$ & $76(42)$ & $0.9(0.6$ to 1.3$)$ & $<0.001$ \\
\hline
\end{tabular}

${ }^{\star} \mathrm{p}<0 \cdot 05$.

TABLE IV - Number (percentage) of preterm infants who had developed eczema, allergic reactions, or wheezing or asthma at 18 months after term according to family history of atopy and initial diet

\begin{tabular}{|c|c|c|c|c|c|c|c|}
\hline & \multicolumn{3}{|c|}{ Family history of atopy } & \multicolumn{3}{|c|}{ No family history of atopy } & \multirow{2}{*}{$\begin{array}{l}\text { Interaction } \\
\text { between } \\
\text { family history } \\
\text { and diet } \\
\text { (p value) }\end{array}$} \\
\hline & $\begin{array}{l}\text { Term } \\
\text { formula } \\
(n=43)\end{array}$ & $\begin{array}{l}\text { Preterm } \\
\text { formula } \\
(n=42)\end{array}$ & $\begin{array}{c}\text { Odds ratio } \\
\text { (95\% confidence } \\
\text { interval) }\end{array}$ & $\begin{array}{c}\text { Term } \\
\text { formula } \\
(\mathrm{n}=124)\end{array}$ & $\begin{array}{l}\text { Preterm } \\
\text { formula } \\
(n=122)\end{array}$ & $\begin{array}{c}\text { Odds ratio } \\
\text { (95\% confidence } \\
\text { interval) }\end{array}$ & \\
\hline Eczema & $7(16)$ & $12(29)$ & $2 \cdot 0(0.7$ to 5.9$)$ & $25(20)$ & $17(14)$ & $0.6(0.3$ to 1.3$)$ & \\
\hline \multicolumn{8}{|l|}{ Reactions to: } \\
\hline Cows' milk & $3(7)$ & $3(7)$ & $1 \cdot 0(0.2$ to $5 \cdot 3)$ & $6(5)$ & $5(4)$ & $0.8(0.3$ to 2.9$)$ & \\
\hline All foods & $8(19)$ & $6(14)$ & $0 \cdot 7(0 \cdot 2$ to $2 \cdot 3)$ & 14 (11) & $7(6)$ & $0.5(0.2$ to 1.2$)$ & \\
\hline Drugs & $3(7)$ & $3(7)$ & $1.0(0.2$ to 5.3$)$ & $6(5)$ & $2(2)$ & $0.3(0.1$ to 1.7$)$ & \\
\hline Wheezing or asthma & $10(23)$ & $9(21)$ & $1.0(0.3$ to 3.0$)$ & $22(18)$ & $30(25)$ & $1.2(0.6$ to 2.3$)$ & \\
\hline Total with any reaction & $18(42)$ & $26(62)$ & $2 \cdot 3(0.9$ to $5 \cdot 3)$ & $55(44)$ & $43(35)$ & $0.7(0.4$ to 1.1$)$ & $<0.02$ \\
\hline
\end{tabular}

Altogether 85 infants in trial B (preterm formula versus term formula) had first degree relatives with a history of atopic disease (table IV). There was no significant difference between dietary groups, nor was there any dietary difference in the larger group without family history of atopy. Among infants fed on preterm formula, however, those with a family history had an odds ratio for developing one or more allergic reactions of 2.3 compared with 0.7 in those without a family history $(p<0.02)$, indicating that the differential impact of diet was not the same in the two groups.

\section{Discussion}

We studied whether early avoidance of cows' milk proteins in neonates protected against later atopy or sensitivity to food and whether the dose of cows' milk protein consumed in the neonatal period influenced the incidence of such reactions or disease. Surprisingly, when subjects were assessed 18 months after term there was no overall protective effect of early feeding with human milk on subsequent reactions to cows' milk, even in a subgroup of infants fed exclusively on human milk for between two and five months. Moreover, in infants randomly assigned to receive a standard formula (containing $14.5 \mathrm{~g}$ protein/l) or a preterm formula with a high cows' milk protein content $(20.0 \mathrm{~g}$ protein/l) there was also no overall difference in the incidence of sensitivity to cows' milk. Moreover we found that feeding infants on human milk, preterm formula, or standard formula made no overall difference to the subsequent incidence of reactions to other foods or drugs or of eczema, wheezing, or asthma.

Subgroup analysis showed the importance of taking a family history of allergy into account. The lack of overall effect of early diet on the later incidence of allergic reactions was due to a significantly higher incidence of allergy in infants fed on preterm formula than those fed on human milk when there was a family history of atopy and a small (non-significant) decrease in all reactions in infants who received preterm formula who did not have a family history. The odds ratios for those with and without a family history who received preterm formula milk in trial A were 3.6 and 0.9 respectively. These were significantly different, and this suggests that diet does indeed have a significantly different impact on later allergic reactions if a child has a genetic predisposition to allergy.

In trial $\mathrm{B}$ infants were fed on a standard formula containing $14.5 \mathrm{~g}$ protein/l or a preterm formula supplying $20.0 \mathrm{~g}$ protein $/ 1$. In the group with a family history of atopy more infants fed on preterm formula than on term formula developed one or more allergic reactions (odds ratio $2 \cdot 3$ ), though this difference was not significant $(p>0.05)$. Conversely, in the group without a family history fewer allergic reactions occurred in infants who received preterm formula (odds ratio $0 \cdot 7$ ), although this was not significant. Nevertheless, these odds ratios were significantly different, suggesting a differential impact of diet (perhaps relating to intake of cows' milk protein) in children with and without a family history of allergy.

The reliability of data on allergy to cows' milk, other allergic reactions, and atopic disease obtained by clinical history is open to question. In this large multicentre study detailed immunological tests would have been impractical and their value controversial. Our study is comparable with others ${ }^{10.12}$ and has the advantage over several questionnaire based studies ${ }^{13-1 \mathrm{n}}$ in that a careful and consistent history was taken (and by the same observer in four centres). In the case of eczema and wheezing historical data were often backed by findings on clinical examination $(60 \%$ of cases of eczema were confirmed). Furthermore, because the study was a blind evaluation of the effects of randomly assigned neonatal diets on the later development of allergic reactions, any underreporting or overreporting applied equally to both feed groups.

Without corresponding data from prospective randomised studies on term infants it is difficult to assess the extent to which our findings apply to infants who are not born preterm. Our observations may help to explain conflicting reports on the relation between breast feeding and atopy. ${ }^{17}$ Food antigens have been implicated in the aetiology of eczema and asthma, ${ }^{1819}$ but the similar incidence of allergic reactions that we found after feeding with formula or breast milk in infants without an atopic family history requires explanation. Preterm infants have immature immuno- 
logical mechanisms, especially those relating to IgE production, ${ }^{21}$ and reduced exposure to anti-idiotype antibodies (thought to be important in the pathogenesis of infantile atopy), ${ }^{212}$ and this may have affected the results. Alternatively, dose related tolerance to cows' milk proteins could develop in immunologically normal preterm or even term infants. Interestingly, Lindfors and Enocksson recently observed that full term infants without a family history of atopy who were fed on formula milk before breast milk had a lower incidence of allergic symptoms up to 18 months. ${ }^{12}$

Our data are relevant to the increasing use of special preterm formulas for low birthweight infants. Although there was no overall increase in allergic reactions when infants were fed on formula rather than human milk, we showed that a familial predisposition to atopy may determine the pattern of allergic response to early diet. The increase in allergic reactions after feeding preterm formula in the subgroup with a family history of atopy, however, must be balanced against mounting evidence of benefits in terms of outcome with special formula milk in neonatal care. ${ }^{23-26}$

1 David TJ. Commentary: prolonged breast feeding and heredity as determinant in infantile atopy. Arch Dis Child 1987;62:273.

2 Autonowicz I, Lebenthal E. Developmental pattern of small intestinal enterokinase and disaccharidase activities in the human fetus. Gastroenterolog 1977;72:1299-303

3 Roberton DM, Paganelli R, Dinwiddie R, Levinsky RJ. Milk antige absorption in the preterm and term neonate. Arch Dis Child 1982;57:369-72.

4 Muller W, Reiger CHL, van der Hardt H. Increased concentrations of milk antibodies in recurrent pulmonary aspiration in infants and young children. Acta Paediatr Scand 1985;74:660-3.

5 Lucas A, McLaughlan P, Coombs RRA. Latent anaphylactic sensitisation of infants of low birth weight to cows' milk proteins. $B r$ Med $\mathcal{F} 1984 ; 289$ : $1254-6$.

6 Lucas A, Gore SM, Cole TJ, et al. Multicentre trial on feeding low birthweigh infants: effects of diet on early growth. Arch Dis Child 1984:59:722-30.

7 Price J. Asthma in children: diagnosis. Br Med f 1984:288:1666-8.
8 Godfrey S. What is asthma? Arch Dis Child 1985;60:997-1000.

Armitage P. Statistical methods in medical research. Oxford: Blackwell. $1971: 429$

10 Van Asperen PP, Kemp AS, Mellis CM. Relationship of diet in the development of atopy in infancy. Clin Allergy 1984;14:525-32.

11 Savilahti E, Taino V-M, Salmenpera L, Siimes MA, Perheentupa J. Prolonged exclusive breast feeding and heredity as determinants in infantile atopy. Arch Dis Child 1987;62:269-73.

12 Lindfors A, Enocksson E. Development of atopic disease after early administration of cow milk formula. Allergy 1988;43:11-6.

13 Bisgaard $H$, Dalgaard $P$, Nyboe J. Risk factors for wheezing during infancy. Acta Paediatr Scand 1987;76:719-26.

14 Kjellman N-IM. Atopic disease in seven-year-old children. Acta Paediat Scand 1977;66:465-71.

15 Croner S, Kjellman N-IM, Eriksson B, Roth A. IgE screening in 1701 newborn infants and the development of atopic disease during infancy. Arch Dis Child 1982:57:364-8.

16 Midwinter RE, Morris AF, Colley JRT. Infant feeding and atopy Arch Dis Child 1987;62:965-7.

17 Taylor B, Wadsworth J, Wadsworth M, Peckman C. Changes in the reported prevalence of childhood eczema since the $1939-45$ war. Lancet 1984;ii: $1255-7$

18 Atherton D, Soothill JV, Sewell M, W'ells RS. A double blind controlled crossover trial of an antigen-avoidance diet in atopic eczema. Luncel $1978 ; \mathrm{i}: 402-4$.

19 Chandra RK. Prospective studies of the effect of breast feeding on incidence of infection and allergy. Acta Paediatr Scand 1979;68:691-9.

20 Michel FB, Bousquet J, Greillier P, Robinet-Levy M, Coulomb Y Comparison of cord blood immunoglobulin $\mathrm{E}$ concentrations and maternal allergy for the prediction of atopic diseases in infancy. 7 Allergy Clin Immunol 1980;65:422-30.

21 Melander L, Carlsson B, Hanson L-A. Secretory IgA and IgM antibodies to coli $\mathrm{O}$ and poliovirus $\mathrm{I}$ antigens occur in amniotic fluid, meconium and saliva from newhorns. A neonatal immune response without antigenic exposurea result of anti-idiotype induction? Clin Exp Immunol 1986;63:555-61.

22 Falth-Magnusson K, Oman H, Kjellman N-IM. Maternal abstention from cow milk and egg in allergy risk pregnancies. Allergy 1987;42:64-73.

23 Brooke $O G$, Wood C, Barley J. Energy balance, nitrogen balance and growth in preterm infants fed expressed breast milk, a premature infant formula and two low-solute adapted formulae. Arch Dis Child 1982;57:898-904.

24 Gross SJ. Growth and biochemical response of preterm infants fed human milk or modified infant formula. $N$ Engl F Med 1983;308:237-41.

25 Lucas A, Morley R, Cole TJ, et al. Early diet in preterm infants and developmental status in infancy. Arch Dis Child 1989;64:1570-8.

26 Lucas A, Brooke OG, Baker BA, Bishop N, Morley R. High alkaline phosphatase activity and growth in preterm neonates. Arch Dis Child 1989:64:902-9.

(Accepted l Fehruary 1990

\title{
Pregnancies in women with and without renal scarring after urinary infections in childhood
}

\author{
Jeanette Martinell, Ulf Jodal, Gunilla Lidin-Janson
}

\section{Abstract}

Objective-To compare the outcome of pregnancy in women with and without renal scarring after childhood urinary infections with that in unmatched controls.

Design-Retrospective study of pregnancies in women prospectively followed up from their first recognised urinary infection.

Setting - Tertiary referral centre in Gothenburg.

Subjects-111 Women attending an outpatient clinic for women with urinary infection during 197583 , of whom 41 (65 pregnancies) were studied (19 women with renal scarring (32), 22 without scarring (33)), and 65 controls (65) randomly selected and matched for parity, age, smoking habits, and date of delivery.

Main outcome measures-Urinary infections and

Departments of Paediatrics and Infectious Diseases, Gothenburg University, East Hospital, S-416 85 Gothenburg, Sweden Jeanette Martinell, MD, senior registrar

Ulf Jodal, MD, senior lecturer Gunilla Lidin-Janson, MD, senior lecturer

Correspondence to: $\mathrm{Dr}$ Martinell, Department of Paediatrics. tions were seen only among women with a history of urinary infection: four women with renal scarring (three of whom had vesicoureteric reflux) developed pyelonephritis and three cystitis, and one woman without scarring developed pyelonephritis. Mean blood pressure was higher among women with severe renal scarring than controls $(4 / 11 v 3 / 44 ; p<0.05)$ before and during pregnancy. There was no signifi- cant difference in the incidence of pre-eclampsia, operative delivery, prematurity, or birth weight.

Conclusions-Women with a history of previous urinary infections had a high incidence of bacteriuria during pregnancy, and those with renal scarring and persistent reflux were prone to develop acute pyelonephritis. The risk of serious complications in pregnancy, however, was not increased in women with severe renal scarring, possibly owing to their continuous clinical supervision.

\section{Introduction}

The long term risks of pyelonephritic renal scarring - for example, complications during pregnancy - have long been known. ${ }^{2}$ The extent of this risk, however, is inadequately known, depending on factors such as the long follow up required and the difficulty in attaining continuity of data. The aim of this study was to determine the incidence of complications during pregnancy in women followed up continuously since their first recognised urinary tract infection in childhood. Special interest was taken in the rate of infections, prematurity of delivery, pre-eclampsia, and operative delivery in women with and without scarring.
Subjects and methods SUBJECTS

There is a long tradition of following up children with urinary tract infections in the Gothenburg area. ${ }^{3}$ 